\title{
An epidemic of picornavirus and adenovirus conjunctivitis
}

\author{
U. G. GHATURVEDi, ASHA MATHUR, U. K. SINGH, A. K. KAPOOR, \\ R. M. L. MEHROTRA, AND R. G. SAXENA \\ From the Upgraded Department of Pathology and Bacteriology, K.G. Medical College, Lucknow, India
}

A pandemic of acute haemorrhagic conjunctivitis occurred all over south-east Asia and Japan during I970 and 1971 (Kono, Sasagawa, Ishii, Sugiura, Ochi, Matsumiya, Uchida, Kameyama, Kaneko, and Sakurai, 1972). A similar epidemic occurred in 1969 in Ghana (Chatterjee, Quarcoopome, and Apenteng, 1970a, b) and Nigeria (Parrott, 1971). In the Indian subcontinent the epidemic of conjunctivitis was first reported in Bombay during April 1971, and later spread almost all over India. Cases of conjunctivitis started increasing at Lucknow during the last week of May 197I, reaching a peak in June, and declining by July. Picorna-like viruses have been isolated from cases in Singapore (Lim and Yin-Murphy, 1971; Yin-Murphy, 1972) and in Japan (Kono and others, 1972). The epidemic at Lucknow was peculiar in that adenoviruses as well as picornaviruses appear to have been present in these cases.

\section{Material and methods}

The study was carried out by the ophthalmologist (RGS) on 253 typical cases of conjunctivitis which presented at Gandhi Memorial and associated hospitals for treatment. Out of 253 patients 84.5 per cent were aged between II and 40 years. The youngest was 3 years old and the oldest 65 years. The illness started unilaterally, and most of the population at Lucknow was affected. There were multiple cases in a family and the infection could be transmitted even by casual conversation. The incubation period was less than 24 hours in most cases. The chief complaints were a gritty sensation in the eyes, watering, and photophobia. A few patients had upper respiratory symptoms. Ocular examination revealed redness, oedema of the conjunctiva and lids, subconjunctival haemorrhage in a number of cases, and enlarged preauricular lymph nodes. The cornea remained unaffected. The detailed clinical findings have been reported by Saxena, Bhatia, and Chaturvedi (1972).

\section{LABORATORY STUDIES}

The laboratory investigations included total and differential leucocyte counts and conjunctival swab cultures on blood agar and Robertson's cooked meat medium.

Address for reprints: Dr U. C. Chaturvedi, Upgraded Department of Pathology and Bacteriology, K.G. Medical College, Lucknow226003, India
Bacteria were identified by their morphology, cultural characters, and biochemical reactions. Smears were prepared from conjunctival scrapings of $6 \mathrm{r}$ patients and stained with Giemsa stain to study the pattern of cellular infiltration and to determine whether inclusion bodies suggestive of viral infection would be found.

\section{VIROLOGICAL INVESTIGATIONS}

Conjunctival swabs and scrapings were collected for virological study within 48 hours of the onset of illness. Paired sera were collected from i 5 patients for study of antibody titres.

\section{VIRUS ISOLATION}

This was done on primary rhesus monkey kidney tissue culture. Each sample was inoculated into a group of four tissue culture tubes. These were incubated stationary at $37^{\circ} \mathrm{C}$ and were examined daily for 15 days. Tubes showing cytopathic effects were subcultured.

\section{ADENOVIRUS SEROLOGY}

\section{Haemagglutination test}

The cytopathic agents were tested for haemagglutinin using albino rat and rhesus monkey erythrocytes. It was found that only rat erythrocytes were agglutinated by the isolates; therefore for further experiments only erythrocytes from albino rats were used, taking the precautions described by Rosen (1960). Hyperimmune antisera were raised against two of the isolates in rabbits by the technique of Rosen (1960). After treating the hyperimmune sera with 25 per cent kaolin and absorption with rat erythrocytes, a haemagglutination inhibition (HI) test was performed on all the isolates. The HI tests were repeated in the presence of heterologous antisera (Rosen, 1960). With eight of the selected isolates chessboard titrations were done using the hyperimmune sera described above. Paired sera collected during the acute phase and in convalescence were tested for $\mathrm{HI}$ antibodies against one of the isolates.

\section{ELECTRON MICROSCOPY}

One of the agents was studied under the electron microscope in the monkey kidney tissue culture fluid and after passage in HeLa cells at Birmingham.

\section{IDENTIFICATION}

This agent was finally identified at the Virus Reference Laboratory, London, by a neutralization test. 


\section{PICORNAVIRUS SEROLOGY}

In nine pairs of sera, antibodies were studied by neutralization tests against the $15477 / 7$ I strain isolated by $\mathrm{Dr}$ Chang from an epidemic of conjunctivitis in Hong Kong in 1971 and also against the EC2/71 strain isolated from a case of acute haemorrhagic conjunctivitis in Singapore in $197 \mathrm{I}$, containing 30 to $100 \mathrm{TGD}_{50}$ infective doses. Equal volumes of suspensions of these viruses and each dilution of a doubling dilution series of sera were held at $37^{\circ} \mathrm{C}$ for I $\mathrm{hr}$ before each of two HeLa tissue cultures was inoculated with $0.2 \mathrm{ml}$ of mixture containing 30 to Ioo $\mathrm{TCD}_{50}$ of virus. The inoculated cultures were rolled at $37^{\circ} \mathrm{C}$ and read on the third and fourth day.

\section{Results}

\section{LABORATORY FINDINGS}

Total and differential leucocyte counts were done on 183 patients. Normal counts were found in $14^{8}$ patients $(80.8$ per cent). Leucocytosis was observed in 34 patients ( 18.7 per cent) and leucopenia in one. The differential leucocyte counts showed neutrophilia in three cases, lymphocytosis in $4^{\circ}$, and eosinophilia in thirty.

\section{BACTERIOLOGICAL FINDINGS}

Staphylococcus aureus was isolated from seven patients (2.7 per cent).

\section{EXAMINATION OF CONJUNCTIVAL SCRAPINGS}

The findings from conjunctival scrapings are shown in Table I. Intranuclear masses suggestive of inclusion bodies due to adenovirus infection (Fig. I) were present in conjunctival cells of 26 out of 6 I patients $\left(4^{2} \cdot 6\right.$ per cent). In 49 cases both cytological examination and isolation of virus were attempted. In 24 cases adenovirus isolation was positive, and nine of these had intranuclear masses in conjunctival scrapings. Similar intranuclear inclusions were seen in nine of the 25 isolation negative cases. Conversely, nine of the 18 cases with intranuclear masses yielded adenovirus, and of the $3^{I}$ cases without intranuclear masses, I5 were positive for adenovirus. There was thus no correlation between the dense intranuclear masses seen and positive cultures for adenovirus. Infiltration by mononuclear cells (Figs 2 and 3 ) was seen in 40 patients $\left(95^{\circ} 6\right.$ per cent).

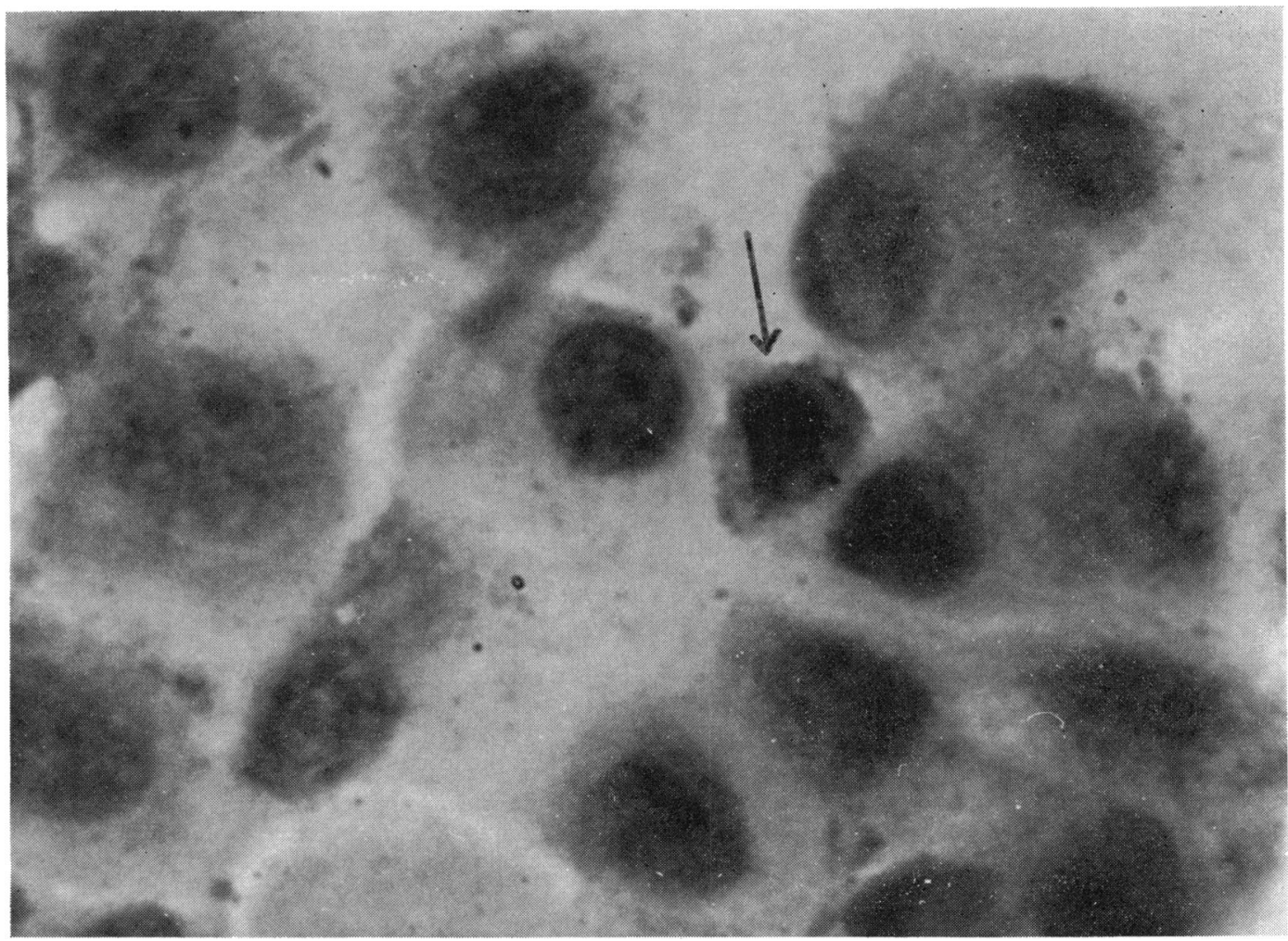

FIG. I Smear of conjunctival scraping. Epithelial cell containing irregular intranuclear inclusion body (arrow). Giesma. $\times 500$ 


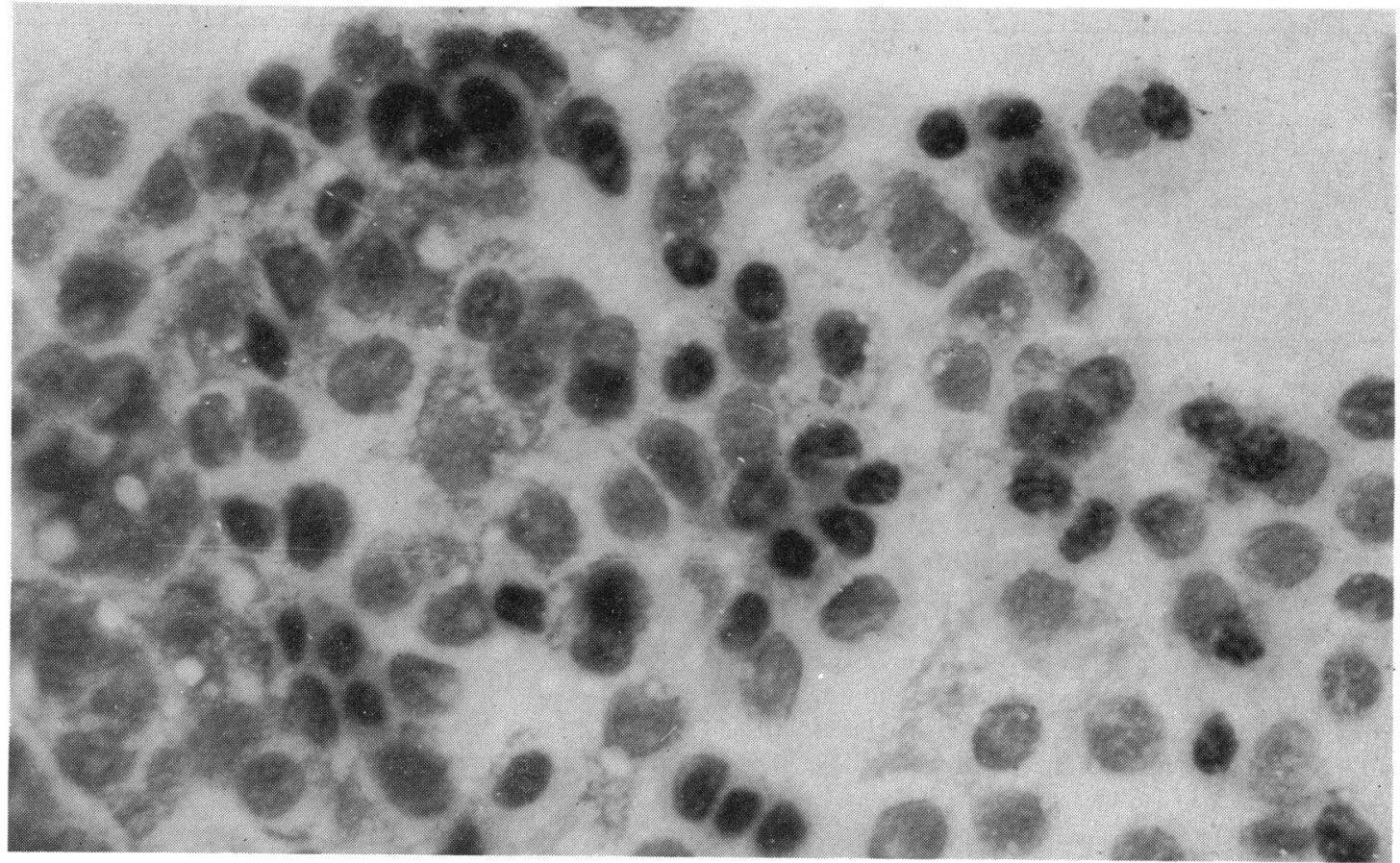

FIG. 2 Smear of conjunctival scraping. Collection of conjunctival epithelial cells with infiltration by mononuclear cells. Giesma. $\times 200$

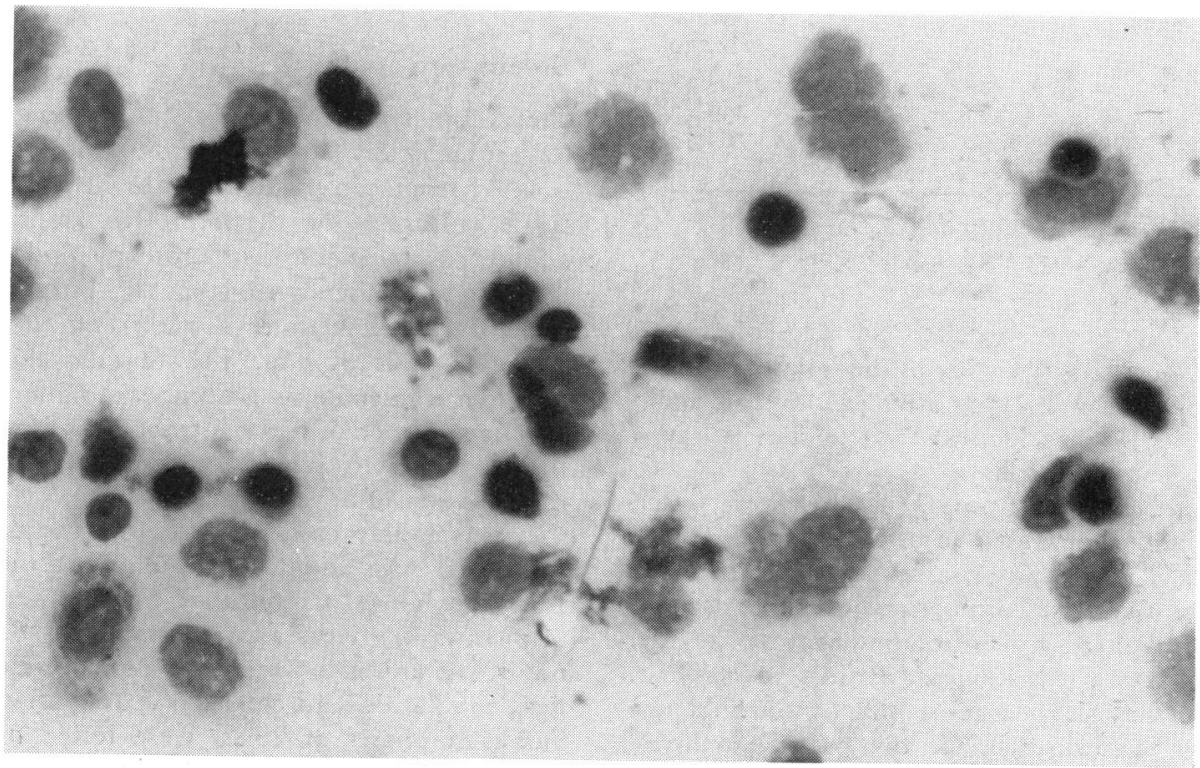

FIG.3 Smear of conjunctival scraping from another patient. Conjunctival epithelial cells and infiltrating mononuclear cells. Giesma. $\times 200$ 
Table I Microscopy of conjunctival smears

\begin{tabular}{|c|c|c|c|c|}
\hline \multirow{2}{*}{ Inclusions } & \multicolumn{3}{|l|}{ Infiltration } & \multirow{2}{*}{ Percentage } \\
\hline & Mononuclear & Mixed & None & \\
\hline Present & 20 & 2 & 4 & $42 \cdot 6$ \\
\hline Absent & 20 & 3 & 12 & $57 \cdot 4$ \\
\hline Total & 40 & 5 & 16 & 100 \\
\hline
\end{tabular}

\section{VIROLOGICAL INVESTIGATIONS}

Viruses causing a cytopathic effect (CPE) of the kind caused by adenoviruses were isolated from conjunctival swabs from 74 patients. The CPE was observed after 7-IO days' incubation of inoculated cultures. All these isolates haemagglutinated rat, but not rhesus monkey, erythrocytes. Altogether 62 of the isolates $(84.5$ per cent) gave a positive haemagglutination inhibition test with hyperimmune antiserum raised in rabbits against two of the isolates. Table II shows the findings of the chessboard HI tests done on eight isolates.

Table II Results of chessboard HI test

\begin{tabular}{llc}
\hline Specimen no. & $\mathrm{K}$ no. & $H I$ \\
\cline { 3 - 3 } 71346 & 2779 & $128 * / 32 \dagger$ \\
71379 & 2788 & $32 / 64$ \\
71359 & 2790 & $64 / 128$ \\
71320 & 2866 & $32 / 16$ \\
71250 & 2876 & $64 / 32$ \\
71445 & 2654 & $256 / 128$ \\
71456 & 2658 & $256 / 128$ \\
71354 & 2940 & $64 / 128$ \\
& &
\end{tabular}

* Numerator $=$ highest antigen dilution

$\dagger$ Denominator $=$ highest antibody dilution

Electron microscopy revealed particles of typical adenovirus morphology in one of the isolates. Similar virus particles were observed after passing this agent in HeLa cells. It was identified as adenovirus type 2 by serum neutralization.

Paired sera collected from 15 patients were tested for $\mathrm{HI}$ antibodies against one of the isolated adenolike agents. A significant rise in antibody titre was seen in seven patients. Paired sera from nine of these patients were tested for antibodies against the two strains of picorna viruses and against adenovirus. Six pairs of sera showed more than a fourfold rise against $\mathrm{EC}_{2} / 7$ I strain, while in two pairs a small rise of less than 8 to a titre of 12 was seen. None of the sera had antibodies against the I5477/7 I strain (Table III). Furthermore, adeno-like viruses were
Table III Picornavirus antibodies in paired sera

\begin{tabular}{|c|c|c|c|c|}
\hline \multirow{2}{*}{ Specimen no. } & \multirow{2}{*}{$\begin{array}{l}\text { Date of } \\
\text { onset } \\
\text { in } 1971\end{array}$} & \multirow{2}{*}{$\begin{array}{l}\text { Date of } \\
\text { collection } \\
\text { of sera }\end{array}$} & \multicolumn{2}{|c|}{ Picornavirus antibodies } \\
\hline & & & $15477 / 7 I$ & $E C 2 / 7 I$ \\
\hline 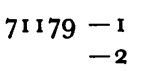 & Io June & $\begin{array}{l}\text { I I June } \\
\text { 28 June }\end{array}$ & $\begin{array}{l}<16 \\
<16\end{array}$ & $\begin{array}{l}<8 \\
<8\end{array}$ \\
\hline $\begin{array}{r}71198-1 \\
-2\end{array}$ & I 4 June & $\begin{array}{l}\text { I J June } \\
3 \text { July }\end{array}$ & $\begin{array}{l}<16 \\
<16\end{array}$ & $\begin{array}{r}<8 \\
12\end{array}$ \\
\hline $\begin{array}{r}71290-1 \\
-2\end{array}$ & 26 June & $\begin{array}{l}28 \text { June } \\
\text { 18 July }\end{array}$ & $\begin{array}{l}<16 \\
<16\end{array}$ & $\begin{array}{r}<8 \\
32\end{array}$ \\
\hline $\begin{array}{r}71315-1 \\
-2\end{array}$ & 29 June & $\begin{array}{l}\text { I July } \\
\text { I } 8 \text { July }\end{array}$ & $\begin{array}{l}<\mathrm{I} 6 \\
<\mathrm{I} 6\end{array}$ & $\begin{array}{r}<8 \\
12\end{array}$ \\
\hline $\begin{array}{c}* 71327-1 \\
-2\end{array}$ & I July & $\begin{array}{l}2 \text { July } \\
25 \text { July }\end{array}$ & $\begin{array}{l}<\mathrm{I} 6 \\
<\mathrm{I} 6\end{array}$ & $\begin{array}{r}<16 \\
128\end{array}$ \\
\hline $\begin{array}{r}71360-1 \\
-2\end{array}$ & 4 July & $\begin{array}{l}5 \text { July } \\
25 \text { July }\end{array}$ & $\begin{array}{l}\text { NT } \\
\text { NT }\end{array}$ & $\begin{array}{r}<8 \\
32\end{array}$ \\
\hline $\begin{array}{c}* 71370-1 \\
-2\end{array}$ & 4 July & $\begin{array}{l}6 \text { July } \\
27 \text { July }\end{array}$ & $\begin{array}{l}<\mathrm{I} 6 \\
<\mathrm{I} 6\end{array}$ & $\begin{array}{r}<8 \\
24\end{array}$ \\
\hline $\begin{array}{r}71433-1 \\
-2\end{array}$ & 8 July & $\begin{array}{l}\text { I0 July } \\
\text { 30 July }\end{array}$ & $\begin{array}{l}\text { NT } \\
\text { NT }\end{array}$ & $\begin{array}{r}<8 \\
96\end{array}$ \\
\hline $\begin{array}{r}71653-1 \\
-2\end{array}$ & I9 Aug. & $\begin{array}{l}20 \text { Aug. } \\
6 \text { Sept. }\end{array}$ & $\begin{array}{l}\text { NT } \\
\text { NT }\end{array}$ & $\begin{array}{l}<8 \\
128\end{array}$ \\
\hline
\end{tabular}

${ }^{*}$ Rising levels of antibody to adenovirus NT $=$ Not tested

isolated from conjunctival swabs of the two patients (71327 and 71370) in whose sera rising antibodies against the $\mathrm{EC}_{2} / \mathrm{7I}_{\mathrm{I}}$ strain were found, as well as rising levels of antibody to adenovirus ( $<10$ to 80 and $<$ Io to 40 respectively).

\section{Discussion}

The findings of the present study demonstrate that 62 antigenically identical cytopathic agents were isolated from conjunctival swabs in monkey kidney tissue culture. One of them was found to be an adenovirus by electron microscopy and was finally identified as adenovirus type 2. Further evidence of adenovirus infection was the rising antibody titres in seven pairs of sera. The findings thus point to adenovirus infection in a number of patients.

The presence of dense intranuclear masses suggestive of adenovirus inclusions did not correlate with the isolation of adenovirus.

From similar cases of epidemic conjunctivitis in south-east Asia and Japan (Kono and others, 1972; Lim and Yin-Murphy, 1971), two different strains of picorna-like viruses have been isolated. We could not isolate any such agent from our specimens. Therefore, the paired sera collected during acute and convalescent phases of illness were tested for the presence of antibodies against picornaviruses. Rising titres against EC2/7I strain (isolated at Singapore in 1971) were observed in six out of nine pairs of sera 
tested. This indicates that the picorna-like virus was also implicated in the aetiology of the cases at Lucknow. It may be mentioned that the $\mathrm{EC}_{2} / 7 \mathrm{I}$ strain is antigenically similar (Yin-Murphy and Lim, I972) to that isolated by Kono and others (1972) in Japan. The findings thus show that the epidemic at Lucknow was similar to that in Singapore and Japan. Our failure to isolate the picornavirus may be because we used only primary monkey kidney tissue cultures, as was also found by Lim and Yin-Murphy (1971).

The interesting aspect of the epidemic at Lucknow has been the presence of adenoviruses as well as picornaviruses in many patients. In two of the patients from whose conjunctival swabs adenovirus was isolated, rising antibody titres against $\mathrm{EC}_{2} / 7 \mathrm{I}$ were also present. A similar double infection has been observed by Dr M. S. Pereira (personal communication) in an epidemic of conjunctivitis in London. Another peculiar feature of this epidemic in India has been the observation of neurological complications. In three patients we observed paresis of the soft palate which developed after the conjunctivitis (Saxena and others, I972) had subsided. Similar findings of lumbar radiculomyelopathy have been observed in Bombay by Wadia (personal communication). It is not certain whether these complications were aetiologically related to the conjunctivitis or if they are merely coincidental.

\section{Summary}

A pandemic of acute haemorrhagic conjunctivitis occurred in south-east Asia during 1970 and 1971, and became epidemic in Lucknow in May $197 \mathrm{I}$. From the conjunctival swabs adenovirus-like agents were isolated in monkey kidney tissue culture; one was typed as adenovirus 2. In paired sera rising antibody titres were found against an adeno-like agent isolated and the picornavirus $\left(\mathrm{EC}_{2} / 7 \mathrm{I}\right)$ isolated in Singapore. The epidemics in south-east Asia were caused by a picornavirus while in Lucknow both adenovirus and picornavirus appeared to be implicated.

We thank Dr M. S. Pereira and Dr H. G. Higgins of the Virus Reference Laboratory, Colindale, London, for typing the adenovirus, detection of picornavirus antibodies, and reading the manuscript of this paper; and $\mathrm{Dr} T . \mathrm{H}$. Flewett (Regional Virus Laboratory, Birmingham) who also read the paper and examined our isolates by electron microscopy. Part of the study was supported by a grant from the Indian Council for Medical Research.

\section{References}

ChatTerjee, s., QUARcoopome, c. o., and APEnteng, A. (I970a) Ghana med. F., 9, 9

$$
\text { (1970b) Brit. 7. Ophthal., 54, } 628
$$

KONO, R., SASAGAWA, A., ISHII, K., SUGIURA, s., OGHI, M., MATSUMIYA, H., UCHIDA, Y., KAMEYAMA, K., KANEKO, M., and SAKURAI, N. (I972) Lancet, I, I I 9 I

LIM, K. H., and YIN-MURPHY, M. (1971) Singapore med. $7 .$, 12, 247

PARROTT, W. F. (I97I) Practitioner, 206, 253

Rosen, L. (I 96o) Amer. F. Hyg., 71, 120

SAXENA, R. C., Bhatia, м., and chaturVedi, u. c. (1972) Orient. Arch. Ophthal., ro, 253

Yin-MurPhy, м. (1972) S.-E. Asian 7. trop. Med. publ. Hlth, 3, 303

- 